\title{
Otic Suspension Dosage Form
}

National Cancer Institute

\section{Source}

National Cancer Institute. Otic Suspension Dosage Form. NCI Thesaurus. Code C91177.

A suspension intended for administration either on the outer ear or into the auditory canal. 